\title{
LOCAL POLITICS AND PUBLIC HEALTH IN MID-NINETEENTH-CENTURY PLYMOUTH
}

by

\author{
MARK BRAYSHAY AND VIVIEN F. T. POINTON*
}

\section{INTRODUCTION}

IN the mid-nineteenth century, Plymouth ranked as one of Britain's most unhealthy towns. ${ }^{1}$ Overcrowding was as bad as that encountered in all but the most pernicious blackspots of London, Liverpool, or Manchester. ${ }^{2}$ Between 1841 and 1850 , the rate of mortality had averaged twenty-five per thousand, a figure as high as the worst of the nation's industrial cities ${ }^{3}$ (Table I). Rapid population growth was an experience that Plymouth shared with a great many other English towns in the early years of Queen Victoria's reign. 'So too was the failure of the outmoded urban administrative bodies to cope with the new kinds of problems created by this unprecedented growth.

Public health issues and agitation for local political reform inevitably became interlinked in provincial towns. ${ }^{5}$ Plymouth was no exception. As the old ruling élite tried to protect their threatened monopoly of local civic institutions, a tide of criticism about their handling of public health matters provided an ideal outlet for the increased political awareness of Plymouth's new breed of activists. 6 Derek Fraser has argued that the mid-nineteenth-century political activist "pitched his tent in whatever battlefield was open to him".? For six momentous years, public health was Plymouth's

*Mark Brayshay, BA, PhD, and Vivien F. T. Pointon, BA, MSc., Faculty of Science, Plymouth Polytechnic, Devon PL4 8AA.

Abbreviations: Parliamentary Papers (PP); Public Record Office (PRO); Devon Record Office (DRO); General Board of Health (GBH).

\footnotetext{
${ }^{1}$ Modern Plymouth comprises the three formerly separate towns of Plymouth, East Stonehouse and Devonport (or Plymouth Dock). In the nineteenth century Plymouth and East Stonehouse had already coalesced but Devonport was still separate, both physically and administratively (see map). In this article the name Plymouth refers to Plymouth and East Stonehouse, but not to Devonport.

${ }^{2}$ W. J. Odgers, A report on the sanitary conditions of Plymouth, 1847, p. 29.

${ }^{3} \mathrm{R}$. Rawlinson, Report to the General Board of Health on a preliminary inquiry into the sewerage, drainage and supply of water, and the sanitary condition of the inhabitants of the Borough of Plymouth, Plymouth, 1852, p. 6.

4 For a general study of urban growth see B. T. Robson, Urban growth: an approach, London, Methuen, 1973, pp. 45-90.

${ }^{3}$ See D. Fraser, Urban politics in Victorian England, Leicester University Press, 1976, ch. 7; E. Gauldie, Cruel habitations: a history of working-class housing 1780-1918, London, Allen \& Unwin, 1974, ch. 11.

'C. E. Welch, 'Municipal reform in Plymouth', Reports and Transactions of the Devonshire Association for the Advancement of Science, 1964, 96: 318-338. Local politics in Plymouth depended on personalities and local events rather than on national politics. The labels "Whig" or "Tory" are too sharp to be appropriate in Plymouth.

${ }^{7}$ Fraser, op. cit., note 5 above, p. 9.
} 


\section{Local politics and public health in mid-nineteenth-century Plymouth}

local political battlefield and when, in 1854, the fighting was ended, a new regime gained control, more accountable and considerably more sensitive than the body which had been swept away.

While it could be argued that local public health issues might have been sufficient in themselves to precipitate the kind of political change achieved in Plymouth and elsewhere in the mid-nineteenth century, there can be little doubt that the influence and work of Edwin Chadwick provided a vital national context within which local squabbles were resolved. ${ }^{8}$ It was Edwin Chadwick who, after years of work devising a new Poor Law, turned his attention to the question of public health. With the same energy and singlemindedness he had shown in exposing the weakness of the old Poor Law system, Chadwick assembled a battery of evidence about health and living conditions in Britain, which not only shocked, but also outraged the nation. The publication in 1842 of his Report on the sanitary condition of the labouring population was one of the most influential and far-reaching Blue Books of the whole Victorian era.9 Ultimately, Chadwick's efforts led to the Public Health Act of 1848 which, though it fell well short of the compulsory new public health administration he had campaigned for, nonetheless gave local pressure groups a new weapon with which to fight their own separate battles for reform. In Plymouth, the Act prompted one of the most acrimonious political arguments in the long history of the town.

TABLE I POPULATION AND MORTALITY IN PLYMOUTH, 1841-50

$\begin{array}{crrc}\text { Year } & \text { Population* } & \text { Deaths } & \begin{array}{c}\text { Death Rate } \\ \text { (per thousand) }\end{array} \\ 1841 & 38,110 & 829 & 21.75 \\ 1842 & 39,693 & 1,107 & 27.89 \\ 1843 & 41,277 & 887 & 21.49 \\ 1844 & 42,860 & 1,022 & 23.85 \\ 1845 & 44,430 & 749 & 16.86 \\ 1846 & 46,026 & 1,030 & 22.38 \\ 1847 & 47,609 & 1,148 & 24.11 \\ 1848 & 49,193 & 1,268 & 25,78 \\ 1849 & 50,776 & 1,876 & 36.95 \\ 1850 & 52,359 & 1,363 & 26.03 \\ & & & \\ \text { Total } & 452,333 & 11,279 & 24.94\end{array}$

Note

In the seven years before the cholera epidemic of 1849, Plymouth's mortality rate averaged 23 per thousand. Thus, even without the impact of cholera mortality on the death rate there were sufficient grounds for a General Board of Health Inquiry.

*These are Registrar General Estimates at 31 December.

Sources: Rawlinson Report, 1853; Plymouth and Devonport Weekly Journal, 29 January 1852; Odgers Report, 1847.

The principal objective of the 1848 Public Health Act was the establishment of a

- Gauldie, op. cit., note 5 above, p. 131-141.

'D. Fraser, Power and authority in the Victorian city, Oxford, Blackwell, 1979. Edwin Chadwick, Report on the sanitary condition of the labouring population of Great Britain (1842), edited by M. W. Flinn, Edinburgh University Press, 1965. 
General Board of Health appointed to encourage and co-ordinate a network of new, local boards which, it was hoped, would soon be formed in all the towns in the country. These Local Boards of Health were to assume responsibility for ensuring adequate and efficient water supply, sewage, and refuse disposal systems; and, through the appointment of local medical officers, to oversee all matters related to public health. The fundamental flaw in the legislation was that it was not made compulsory. ${ }^{10}$

The wrangle in Plymouth over whether to adopt the terms of the 1848 Act was not unique. It was matched by similar disputes elsewhere. In their first major report early in 1854, the General Board of Health were able to name only 284 towns that had formally requested the application of the Act, and a mere 182 had completed the necessary legal process by December 1853." While the number of new requests was said to be increasing, many of the towns making an application to the Board either already possessed a relatively good public health record, or they were very small in population and were unlikely to be able to afford the measures necessary for improvement. In large towns the situation was rather different. Although some like York, Southampton, Dover, and Coventry had very readily adopted the Act, others became notorious for their stubborn resistance. ${ }^{12}$ Birmingham, Newcastle, and Hull, for example, all used a ploy that became fairly common practice in the 1850 s wherever vested interests stood to forfeit either political power or control of civic finances should Chadwick's arrangements be applied in their borough. The tactic employed was to frustrate the introduction of a new board of health in the town by substituting, or perhaps merely revising, an existing local act of Parliament which legislated on matters such as urban water supply, drainage, and refuse removal. ${ }^{13}$ These local acts were rarely sufficiently comprehensive to cope with the mounting sanitary deficiencies of Britain's growing towns and, moreover, they were often excessively costly to local ratepayers. But they were a way of preserving local political power in the hands of those accustomed to wielding it and they eliminated any prospect of interference by the General Board of Health in local matters.

The anti-Public Health Act lobby in Plymouth tried to promote two local bills in order to circumvent the need to adopt Chadwick's controversial new measures. One was yet another revision of the town's "Improvement" Act, while the other was a specific attempt to remedy the woefully inadequate local water supply arrangements. ${ }^{14}$ Indeed, a relentless and hostile campaign against the 1848 Public Health Act was waged for almost six years, during which time the appalling conditions in Plymouth steadily deteriorated..$^{13}$

Local politics in provincial towns were everywhere in the melting-pot in midVictorian times, and a number of notable case studies have already been published by

${ }^{10}$ Public Health Act 1848, 11 \& 12 Vict. Cap. 63.

"PP (1854), vol. XXXV, Report of the General Board of Health, 1848-54, pp. 42-43.

12 Ibid., p. 43.

${ }^{13}$ Ibid., p. 44. See also J. Smith, Report to the General Board of Health on a preliminary enquiry into the sewerage, drainage, and supply of water, and the sanitary condition of the inhabitants of the town and borough of Kingston upon Hull, 1850.

${ }_{14}$ PRO, MH 13/144 fo. 960/53, Stevens to Commissioners, 25 March 1953.

is See for example: PRO, MH 13/144 fo. 1189/53, Cookworthy to Commissioners, 15 April 1853; fo. 1579/53, Martin to General Board of Health, 23 May 1853; fo. 8/54, 'Deaths from Cholera' November and December 1853. 


\section{Local politics and public health in mid-nineteenth-century Plymouth}

other writers. ${ }^{16}$ But very little attention has so far been paid to Plymouth, and the aim of this paper, therefore, is to examine public health reform and its links with local political change in this West Devon town with problems as severe as the more notorious cities of industrial Britain.

\section{THE GROWTH OF PLYMOUTH}

The key to Plymouth's health problems lay in its mushrooming population growth, which leapt from only 16,040 in 1801 to more than 52,000 by 1851 (Table II). Moreover, between 1841 and 1851 the town grew by the addition of over 1,600 people a year. This reflected large-scale migration into Plymouth from West Devon and Cornwall due not only to the lure of the apparent opportunities afforded by the town, but also to the low agricultural wages then prevalent in the South West and the closure of tin and copper mines which drove people from the surrounding districts. ${ }^{17}$

Unfortunately this massive influx of people was not matched by the building of new houses, and serious overcrowding resulted. Large houses vacated by the middle classes in the old commercial core of Plymouth were subdivided and multi-occupied by the working classes to an extent where conditions became a scandal. Claremont Street, for example, housed 614 people in only sixty dwellings. New Street, near the Barbican, contained twenty-three houses and 598 people - an average of twenty-six to each dwelling. In three cases a staggering sixty-six, seventy-five, and ninety-one persons were found sharing a house. Other blackspots included Basket Street, where there were more than twenty people per house; Stillman Street with thirteen, and Lower Street with fifteen. Indeed, in one court off Lower Street there were 171 people in six houses, none of which was drained, and all shared a single stand-pipe for their supply of water. ${ }^{18}$

\begin{tabular}{ccc}
\multicolumn{2}{c}{ TABLE II. POPULATION GROWTH IN PLYMOUTH } & 1801-1901 \\
Population & $\%$ Change \\
1801 & 16,040 & \\
1811 & 20,803 & 29.7 \\
1821 & 21,591 & 3.8 \\
1831 & 31,080 & 43.9 \\
1841 & 36,520 & 17.5 \\
1851 & 52,221 & 43.0 \\
1861 & 62,599 & 19.9 \\
1871 & 68,833 & 10.0 \\
1881 & 73,863 & 7.3 \\
$1891^{*}$ & 84,253 & 14.1 \\
1901 & 107,636 & 21.0
\end{tabular}

Sources: Census Reports 1801-1901.

*There were boundary changes between the 1881 and 1891 censuses.

\footnotetext{
${ }^{16}$ For example, B. D. White, A history of the Corporation of Liverpool, Liverpool, 1951; J. Toft, 'Public health in Leeds in the nineteenth century', MA thesis, University of Manchester, 1966; C. Gill, History of Birmingham, Oxford University Press, 1952; D. Large, and F. Round, Public health in mid-Victorian Bristol, Bristol, Bristol Branch of the Historical Association, 1974.

17 See J. Gerrard, Book of Plymouth, Plymouth, 1982.

18 Odgers, op. cit., note 2 above, p. 14.
} 


\section{Brayshay and V. F. T. Pointon}

Part of the problem was an acute shortage of suitable building land. The expansion of Plymouth was impeded by several large private estates that encircled the town. Land was only slowly released to speculative builders and often on unfavourable leasehold terms that encouraged the erection of only the cheapest and most inferior types of dwelling. ${ }^{19}$ Some sites in the town were simply too steep to be used for housebuilding; others were too marshy. And in a town where casual dock labour was a key form of employment, working men were often reluctant to live too far from the wharfingers' pitches and thereby risk losing the chance of being hired.

As a growing port, nineteenth-century Plymouth acquired a cosmopolitan population that set it apart from the rest of Devon and Cornwall. As the depot for colonial emigration sponsored by the government, Plymouth hosted large groups of Irish en route to Australia, Canada, and elsewhere..$^{20}$ Steamers provided regular contact with both Belfast and Cork and by 1851 a permanent Irish community was well established in one of the least salubrious parts of Plymouth. ${ }^{21}$ Imports including chemicals, timber, grain, and hides supported local industries like candle-, soap- and starchmaking, furniture- and boat-building, biscuit-baking, brewing, distilling, and tanning. Plymouth also served as a major livestock market for a large tract of Devon and Cornwall. Thus huge numbers of "Devon Ruby" cattle were driven through the streets into the heart of the town, where the slaughterhouses and butchers were kept busy. Indeed, cowkeeping was common throughout Plymouth in the nineteenth century, ${ }^{22}$ and, while the practice ensured a supply of fresh dairy produce, the effect of keeping farm animals in domestic premises lining narrow, undrained streets can have done little to improve the health record of the town.

\section{PLYMOUTH'S IMPROVEMENT COMMISSIONERS}

In April 1824, a local Act of Parliament dating back to 1770 had been amended for the third time: "for better paving, lighting, cleansing, watching and improving the town and borough of Plymouth in the county of Devon, and for regulating the Police thereof, and for removing and preventing nuisances and annoyances therein". ${ }^{23}$ The amendments comprised clauses that established a freshly mandated commission empowered to order the building of public drains, the construction and cleansing of private drains, and the watering and cleansing of streets in the town. On the face of it, Plymouth ought to have been a clean and healthy borough. There were, however, a number of operational difficulties. First, the Commissioners had no power to insist on the installation of adequate drainage for new development. ${ }^{24}$ Ironically, therefore, most of the ill-drained and thus unhealthy areas of the town were on the periphery where new housing was being erected at break-neck speed as soon as land became available. ${ }^{25}$ Second, the establishment of Plymouth Town Council under the terms of

\footnotetext{
19 C. Gill, Plymouth: a new history, Newton Abbot, David \& Charles, 1979, vol. 2, p. 146-148.

${ }^{20}$ M. Brayshay, 'Government-assisted emigration from Plymouth in the nineteenth century', Reports and Transactions of the Devonshire Association for the Advancement of Science, 1980, 112: 185-213.

${ }^{21}$ Gill, op. cit., note 19 above, p. 149.

22 Kelly's Directory of 1856 reveals that there were more than sixty cowkeepers in Plymouth.

${ }^{23}$ PRO, MH 13/144 fo. 8003/49, Corporation of Guardians of the Poor of Plymouth to Alexander Bain, Assistant Secretary to GBH, 25 October 1849.

24 PRO, MH 13/144 fo. 3923/53, Plymouth Improvement Commissioners to GBH, 7 April 1853.

${ }^{2 s}$ Odgers, op. cit., note 2 above, p. 16.
} 


\section{Local politics and public health in mid-nineteenth-century Plymouth}

the Municipal Corporations Act of 1835 had led to divided jurisdiction. ${ }^{26}$ For, although the Act had allowed for local improvement commissioners to surrender their powers to the new councils after 1835 , in Plymouth this had not happened. Thus while the town's water supply was controlled by the Council, other "improvement" matters remained the concern of the Commissioners. ${ }^{27} \mathrm{~A}$ third problem in Plymouth was that by the 1850s most of the Town Council and the Commission were effectively selfelected for life. Though this charge was vehemently denied by both authorities when it was exposed in a government report in 1853, the facts were plain. ${ }^{23}$ A certain number of town councillors were automatic members of the Commission, and they simply coopted their friends to complete the number. Thus, the persons presiding in the town's most powerful administrative bodies could easily ensure their re-election or reappointment to office, and the faces were said "hardly ever to change". ${ }^{29}$

Although there may have been some mismanagement of funds, there is little documentary evidence to suggest any corruption. Local newspapers contained oblique accusations that suggested that some commissioners blocked attempts to require houseowners to improve badly drained, insanitary properties in the worst parts of town because as landlords themselves of these multi-occupied slums, such action would have inflicted a new, unwelcome expense upon their own purses. ${ }^{30}$ Certainly, many commissioners were practising solicitors. And solicitors in Victorian times often managed their clients' funds by investing in property. However, it is hard to be sure about the motives of individual commissioners and the real difficulty seems to have been one of approach and not bad intention. Thus, instead of ensuring that all new houses were properly serviced when they were erected, the Commission installed sanitation here and there when the local outcry about conditions became loudest, and at considerable cost to the ratepayers. ${ }^{31}$ While none of the new local boards of health in England levied a rate of more than $6 d\left(2 \frac{1}{2} p\right)$ in the pound in 1853, the Commission in Plymouth already expected one shilling (5p) and hoped for $1 s 3 d(7 \mathrm{p}){ }^{32}$ Moreover, they had borrowed heavily on the security of the rates. Together the Corporation and the Improvement Commission in Plymouth owed $£ 67,518$ by 1852 . But the town had precious little to show for it.

Neither local authority was prepared to concede the need for any major reform in the way the town's affairs were run, however, and they simply viewed it as a matter of extending the powers they already possessed. But local pressure for more radical change was nevertheless mounting, and one of the key factors was the report published by the Rev. W. J. Odgers. ${ }^{33}$

\section{THE ODGERS REPORT}

One immediate effect of the publication in 1842 of Chadwick's report on the

\footnotetext{
26 PRO, MH 13/144 fo. 3923/53, Rawlinson to GBH, 21 October 1853.

27 Ibid.

28 PRO, MH 13/144 fo. 1170/53, Whiteford to GBH, 14 April 1853.

29 PRO, MH 13/144 fo. 1579/53, Martin to GBH, 27 May 1853.

${ }^{30}$ Plymouth and Devonport Weekly Journal, 15 November 1849, p. 2.

${ }^{31}$ See ibid., 25 October 1849, 16 August 1849, 17 May 1849.

32 PRO, MH 13/144 fo. 4467/53, Rawlinson to GBH, 21 October 1853.

${ }^{33}$ Odgers, op. cit., note 2 above.
} 
sanitary conditions of the labouring population was to give a boost to the recently formed Health of Towns Association. ${ }^{34}$ Branches were soon formed in provincial towns and, following the example set by Liverpool a year earlier, Plymouth's leading Liberal town councillor, George Soltau, called a public meeting at the Mechanics' Institute in 1846 to discuss the subject of public health. The most important outcome was the foundation of the Plymouth branch of the Health of Towns Association, which launched the Plymouth Health of Towns Advocate as a periodical on the model of similar publications produced with success elsewhere. Although the Plymouth Advocate flopped, it did provide the stimulus for one of the most comprehensive public health investigations to be carried out anywhere in Britain. This took the form of a detailed two-year survey co-ordinated by the Rev. W. J. Odgers (Secretary of the new association), who published his findings on the 'Sanitary Condition of Plymouth' in November 1847. Odgers's survey team was supported by voluntary contributions in its study of drainage, refuse removal, water supply, ventilation, the "physical and moral evils from want of sanitary regulation", and the economic costs and benefits of sanitary improvement. ${ }^{35}$

As a Unitarian Minister the Rev. Odgers was daily in contact with Plymouth's slum-dwellers. Although it is hard to piece together a reliable picture of this tireless local campaigner, there can be little doubt of his influence. He seems to have modelled himself upon the famous Dr William H. Duncan, who did so much to draw attention to public health issues in Liverpool; and while Odgers was not a medical man himself, his studies of health matters were no less meticulous. ${ }^{36}$ Odgers was equally at home in championing the rights of Plymouth's sizeable Jewish community; visiting the sick and dying in areas of the town where few middle-class people would have ventured; and in addressing the Plymouth Athenaeum or Mechanics' Institute on the subject of the works of Charles Dickens. ${ }^{37}$ He was, therefore, both an intellectual and a radical and he was singularly successful in making the civic establishment extremely uncomfortable. Nevertheless, he was lampooned and derided in a steady flow of anonymous letters published in the local press between 1846 and 1852. Odgers invariably responded with clever, often withering counter-argument. ${ }^{38}$

While the only immediate result of his efforts was the opening of public washhouses in Hoegate Street in 1850, and despite the press criticism of his report by opponents of public health reform in Plymouth, Odgers's survey was crucial in throwing open the debate in the town. ${ }^{39}$ Chadwick's national survey was perhaps too global, too far removed from local circumstances to stir many ordinary Plymouthians, but the news that their own town was more overcrowded and unhealthy than Liverpool, Manchester, or Nottingham brought a flood of indignation, shock, and outrage.

Odgers's report recognized the special drainage problems posed by Plymouth's

${ }^{34}$ Ibid., p. iv.

ss Ibid., p. v.

36 W. M. Frazer, Duncan of Liverpool, London, Hamish Hamilton Medical Books, 1947.

${ }^{37}$ Plymouth and Devonport Weekly Journal, 1 January 1849; 15 March 1849; 28 December 1948.

38 Ibid., 7 December 1848, 25 January 1849.

${ }^{39}$ See, for example: PRO, MH 13/144 fo. 897/53; fo. 5249/52; and fo. 960/53. 


\section{Local politics and public health in mid-nineteenth-century Plymouth}

coastal site. Large areas were marshy and some streets were actually below sea level at high tides. Thus, basements in Lockyer Street were often flooded with stagnant water from nearby marshes, and in Bath Street some houses were below water level. Union Street and the Octagon - constructed on land reclaimed from the sea to link Plymouth with the neighbouring town of Stonehouse - lay below sea level at higher tides, and the cellars of houses that lined this route were gradually filled with water. ${ }^{40}$ Street drains, where they existed, were often inadequate, in fact only 1,763 houses in the town (out of a total of 4,930) were linked to any kind of drainage system. Moreover, there were more than 2,200 houses with neither a privy nor a water closet. "For want of privies, the people use a tub, which is kept in the house and even in the room where a family of 10 or 12 persons eat, cook and sleep, which is often kept unemptied for days together."41 Indeed, it had become the practice in Plymouth, particularly in the area of the docks, to allow "night soil" to accumulate in heaps until there was a sufficient load to sell as manure to the farms of the Tamar Valley. Odgers declared that many Plymouthians were "living on vast dung heaps". ${ }^{42}$

Much was made at the time of the injurious effects of the noxious gases and vapours given out by decaying refuse. It was a common belief that the miasma, or foul air, itself could spontaneously cause disease. In fact, the accumulations of filth contaminated the town's water supply to the point where dysentery and diarrhoea became endemic. Odgers's surveyors had noted that the subsoil and foundations beneath houses had often become "perfectly saturated" from nearby cesspools. ${ }^{43}$ Living conditions like these must have weakened the population and left them prey to a range of acute infectious diseases as well as chronic wasting diseases like tuberculosis (Table III).

During the 1840s Plymouth experienced serious outbreaks of scarlet fever and smallpox. Whooping-cough regularly claimed the lives of a number of its young victims, and diseases like dysentery and diarrhoea were endemic. Each year, there were between twenty and thirty deaths due to diseases of the bowel; mostly very young or elderly people, but these figures mask the much larger number of sufferers who were weakened by these illnesses, but did not die. As Table III shows, only in 1846 was Plymouth relatively free from some acute infectious disease, and chronic illnesses like tuberculosis took a steady, year by year, toll. But when cholera struck in 1849 , the rate of mortality reached a new peak, caused genuine terror and added fresh, significant impetus to the local public health campaign.

\section{CHOLERA, 1849}

In the earlier cholera epidemic in 1832 , there were 1,031 recorded deaths in the three towns of Plymouth, Stonehouse, and Devonport.44 Some 779 victims of the

${ }^{10}$ Odgers, op. cit., note 2 above, p. 14.

41 Ibid., p. 19.

42 Ibid., p. 21.

${ }^{43}$ Ibid., p. 20.

4 See Gill, op. cit., note 19 above, p. 149. The basis of diagnosis altered between 1832 and 1848. G. R. Larks, 'Plymouth Medical Society in the nineteenth century', unpubl. address to Plymouth Medical Society 23 January 1968, MS. Plymouth Local History Library Collection. In 1832, cholera was confined to the Sutton Pool area of Plymouth. 
M. Brayshay and V. F. T. Pointon

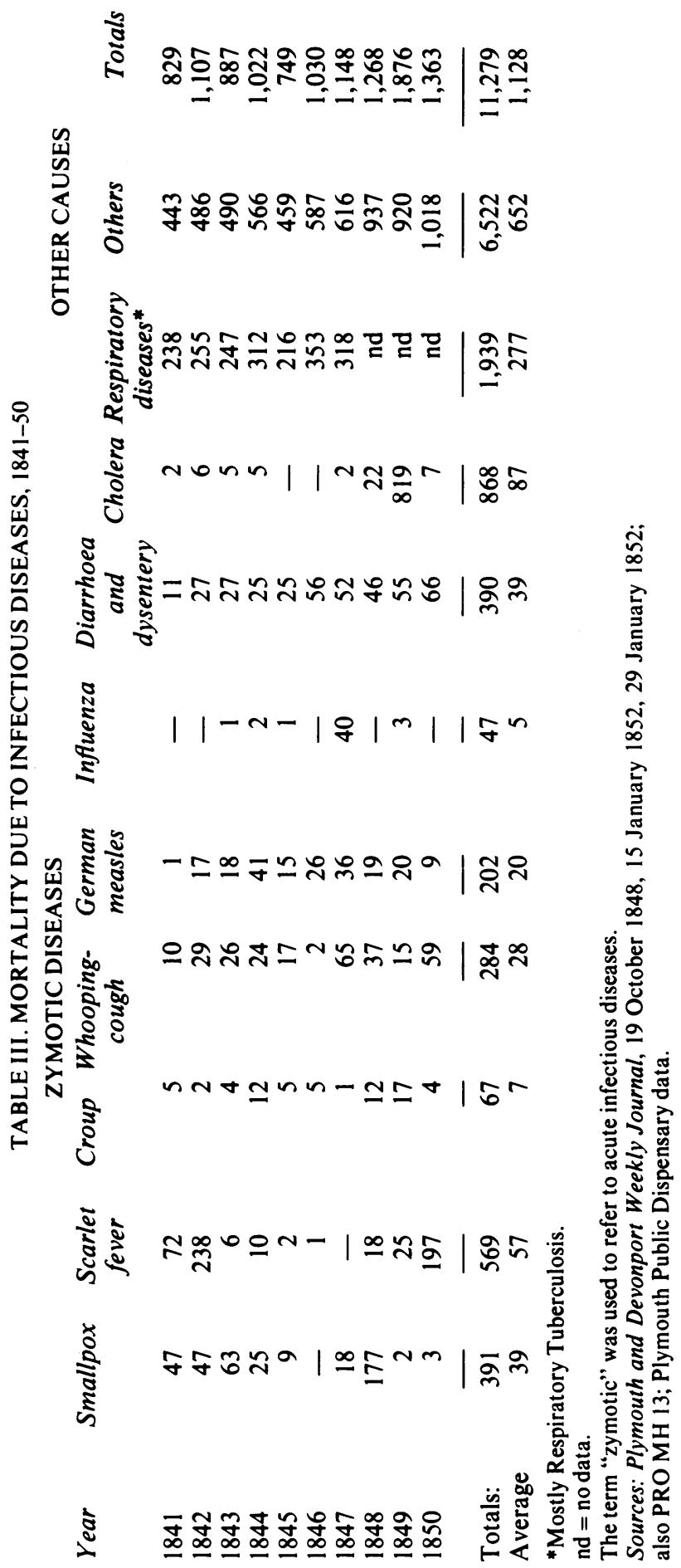




\section{Local politics and public health in mid-nineteenth-century Plymouth}

disease died in Plymouth. For a time, there was a fear that the whole population would be engulfed, but the outbreak was largely confined to the lower classes living in the old inner core of the town around Sutton Pool. By affecting only the poorest sections of the population, the political edge was knocked off the impact of the disease. Largely unaffected by the epidemic, the middle classes quickly forgot the threat.

In 1849, circumstances were different. This time cholera claimed 1,894 lives from amongst the people who contracted the disease in the three towns. ${ }^{45}$ There were 3,360 cases and 819 deaths in Plymouth alone. Moreover, while most deaths occurred in the slum areas of the town, newer middle-class suburbs took their share. The Rev. Odgers must have derived a kind of grim satisfaction. The conditions he had exposed two years earlier had helped to produce exactly the disaster he had predicted.

At first, local newspapers had confidently assured their readers that although other towns were afflicted by cholera, Plymouth was likely to escape. ${ }^{46}$ But in November 1848 , there was a scare when a convict ship, the Cadet, bound for Hobart Town, put into Plymouth because one of the prisoners on board had contracted cholera. The victim was Margaret Farrell, aged twenty-four, who died within hours and was buried at sea out near the Eddystone Reef. ${ }^{47}$ Public anxiety died down, only to be aroused again in June 1849 when the American Eagle, an emigrant ship from Portsmouth, bound for New York, anchored in the sound after six of her passengers had died of cholera during the channel voyage..$^{48} \mathrm{In}$ all, there were almost fifty cases on board the Eagle, but no more fatalities. Plymouth's Port Admiral, Sir William Hall Gage, arranged for disposal of the bodies at sea and the transference of the remaining passengers to quarantine vessels which were anchored off the Hoe. But reports came in that cholera had broken out in the tiny fishing villages of Newton Ferrers and Noss Mayo, only eight miles from Plymouth and panic in the town increased.9

In the days and weeks which followed, Plymouth held its breath. For a time no new cases appeared. The local press carried endless quack remedies and appeals by townspeople to "clear up the burial grounds" or "remedy the evils of stagnant cess pools". ${ }^{\text {so }}$ Early in July, however, it was becoming clear that the disease was taking hold (Table IV). It began to deal its fatal blows in the slum areas, but in the weeks that followed, few districts were safe. A grim peak was reached during the week of 11-18 September, when eighty-seven people died and more than 360 new cases of cholera/choleraic diarrhoea were diagnosed. Thereafter, the epidemic began to decline, but not before whole families had been wiped out (Figure 1).

At the height of the cholera scare, Plymouth's Improvement Commissioners established a temporary board of health, but by December 1849 there was already talk of disbanding it and returning to the status quo..$^{51}$ In any case, the local board had been largely ineffectual.

\footnotetext{
4 Plymouth and Devonport Weekly Journal, 13 December 1849.

46 Ibid., 14 June 1849.

47 Ibid., 30 November 1848.

48 Ibid., 7 June 1849, p. 4.

49 Ibid., 26 July 1849, p. 5.

so Ibid., 5 July 1849; 12 July 1849; 19 July 1849.

51 Ibid., 20 December 1849.
} 
TABLE IV. PEAK CHOLERA WEEKS IN PLYMOUTH JULY-OCTOBER 1849

$\begin{array}{lrccc}\text { 4-11 July } & \text { Cholera } & \begin{array}{c}\text { Choleraic } \\ \text { diarrhoea }\end{array} & \text { Total } & \text { Deaths } \\ \text { 11-17 July } & \text { nd } & \text { nd } & 364 & 81 \\ \text { 17-24 July } & 58 & 168 & 226 & 47 \\ \text { 24-31 July } & 31 & 109 & 140 & 24 \\ \text { 31 July-7 August } & 75 & 164 & 239 & 29 \\ \text { 7-14 August } & 155 & 176 & 331 & 81 \\ \text { 14-21 August } & 132 & 200 & 332 & 72 \\ \text { 21-28 August } & 122 & 165 & 287 & 62 \\ \text { 28 August-4 September } & 94 & 183 & 277 & 45 \\ \text { 4-11 September } & 118 & 205 & 323 & 63 \\ \text { 11-18 September } & 210 & 150 & 360 & 87 \\ \text { 18-25 September } & 89 & 106 & 195 & 60 \\ \text { 25 September-2 October } & 36 & 107 & 143 & 25 \\ & 1,120 & 1,733 & 3,217 & 676\end{array}$

nd $=$ no data.

Note

Between 5 June when cholera was introduced by the visiting ship American Eagle and Christmas 1849, there had been 819 deaths recorded in Plymouth.

Sources: Plymouth and Devonport Weekly Journal, 16 and 23 August 1849, 6, 13, 20, and 27 September 1849, 4 October 1849; Plymouth Public Dispensary data.

Unable to make an impression on either the Plymouth Improvement Commission or the town's Corporation, many individual townspeople complained direct to the General Board of Health. ${ }^{32}$ Surviving letters all carry the same message: Plymouth was fast disappearing under its own filth, and conditions were desperate. In December, the Board received a memorial (petition) from the ratepayers of Plymouth. Signatures were collected by H. C. Martin, a retired army captain whose efforts almost certainly precipitated the subsequent actions of the General Board of Health. But Captain Martin was attacked by the letter-writers in the Plymouth press. ${ }^{33}$

We hear a great deal about the forced application of this Act [Public Health Act] to our own Borough ... the Prime Mover is one Captain Martin - a recent comer-in, whose last abode it is said, and I can readily believe it from his goings-on here, he gave a vast deal of trouble to his neighbours and afterwards left them to settle the account, and to get out of their difficulties the best way they could ....

11 October 1849

Many who were cajoled by Captain Martin and his tail to sign the memorial to the Central Board of Health now regret it. They say they did not exactly understand the result consequent upon the presentation of this memorial .... There appears to be a storm gathering and the Captain may yet be considerably damaged for the prominent part he has taken at the bidding of a few arrant knaves. It is a great misfortune for the poor old Captain that he should 'lend a willing ear' to the evil spirits that have led him on .... Now, he must take care upon the forthcoming enquiry, that he is not completely smashed to ATOMS!

18 October 1849

While there is no mistaking the meaning of these comments, Captain Martin's peti1849.

${ }^{s 3}$ Plymouth and Devonport Weekly Journal, 11 and 19 October 1849. 


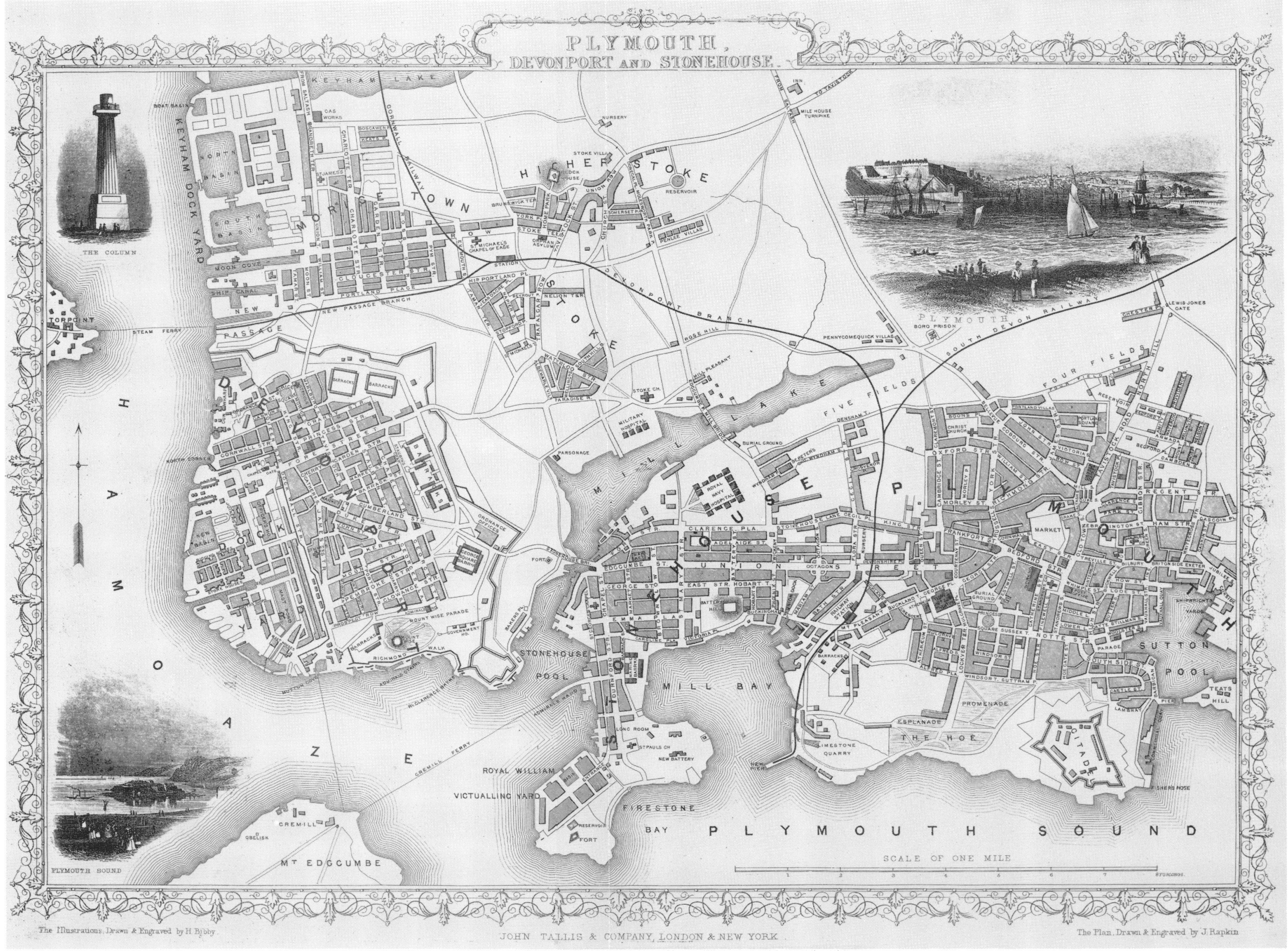

Plymouth c. 1860. (Reproduced by courtesy of Devon Library Services.) 
Cholera Cases in Plymouth July - October 1849

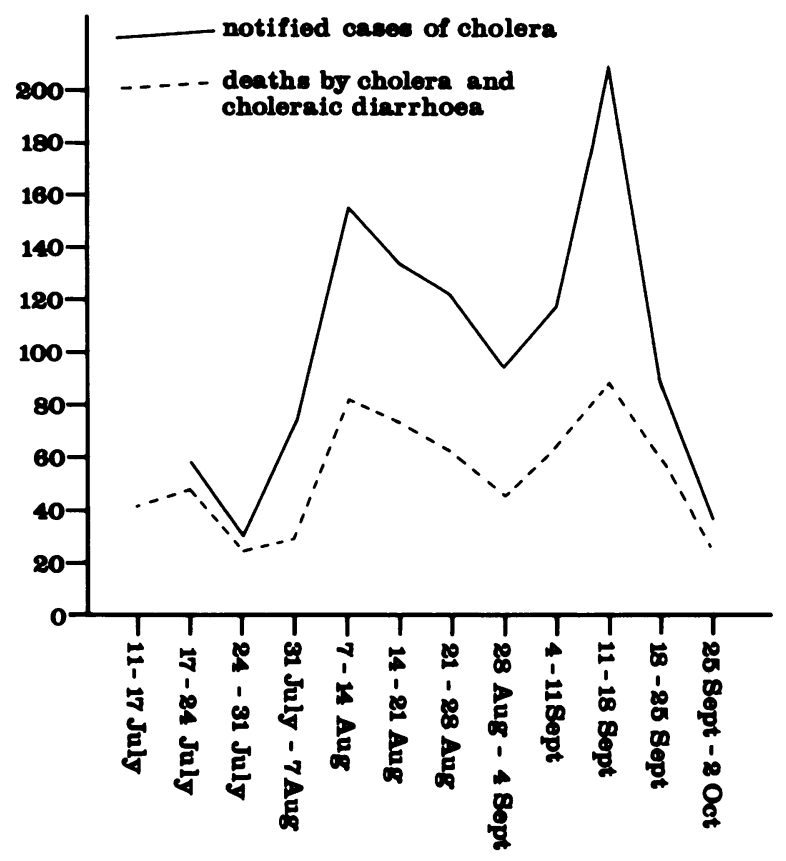

Figure 1.

tion had already been despatched and the wheels were in motion in London. Under the terms of the Public Health Act of 1848 a group of ratepayers equivalent to ten per cent of their total number could bypass the local authorities in their town and make their own direct appeal to the General Board of Health to have the 1848 Act applied to them. Moreover, in certain circumstances, the Board could insist that the Act was adopted. ${ }^{34}$ Where the local level of mortality had averaged twenty-three per thousand over the previous seven years, the terms of the Act allowed for its immediate application to the locality in question. The ratepayers' memorial was therefore able to make its appeal by satisfying both conditions under which the Board could step in. Their reaction was immediately to appoint Robert Rawlinson as Superintendent Inspector of Plymouth with authority to investigate the sewerage, drainage, water supply, and sanitary condition of the town. ${ }^{35}$ It was a bitter pill for the Improvement Commissioners to swallow; their Chairman, William Mortimer, opened a correspondence with the General Board and later with the Local Government Act office, which was to last until at least the late 1860s. His opposition was unfailing, and by January 1867 his letters were no longer even acknowledged. Each was, viewed as just "another of $\mathrm{Mr}$ Mortimer's regular tirades against the Board".36

s4 Public Health Act 1848, 11 \& 12 Vict. Cap. 63.

ss See note 52. Reply to the Ratepayers of Plymouth.

s6 PRO, MH 13/145 fo. 276/67, Mortimer to the GBH; minuted to this effect by the Secretary. 


\section{Brayshay and V. F. T. Pointon}

THE RAWLINSON INQUIRY

Robert Rawlinson was employed by the General Board of Health in the wake of the cholera epidemic as a kind of roving inspector. It was his job to conduct detailed local inquiries into public health matters and to report back to the Board in London. Before coming to Plymouth in January 1852, Rawlinson presided over similar inquiries in Birmingham (1849) and Bradford (1851). ${ }^{57}$ Thus his reputation arrived in the South West well ahead of him, and there is no doubt that the Board's Inspector was regarded with a certain awe and commanded considerable respect in Plymouth.

The inquiry opened on 15 January; all the important local figures assembled, including the Rev. Odgers, William Mortimer, and Captain Martin. Local interest was intense, as Rawlinson took evidence and made his pronouncements. Opponents of the Public Health Act tried hard to sustain their case. For instance, Plymouth's Superintendent Registrar, Mr Pridham, argued that Irish inhabitants and seamen who happened to die in Plymouth falsely inflated the town's average mortality rate. Rawlinson's response was magisterial, "Far from the presence of Irish and other unfortunates in Plymouth being an excuse for the town's appalling health record, this was just the very reason why an enquiry was necessary and why further powers must be obtained".s8

Captain Martin, who had been vilified without mercy in the press, was praised by Rawlinson for his efforts in alerting the General Board of Health to Plymouth's problems. In response, Martin made the following harrowing comment: "When the Cholera was very bad in Quarry Court, I went there with Mr Wright and Dr Budd and we found seven men dead in one room, while there were many others there, some ill and some well, and one of the latter was broiling a piece of pork."s9 The Rev. Odgers presented files of evidence and data to the Inspector, together with new information that amounted to a resurvey of streets examined in 1847 , so that changes that had occurred in the intervening five years could be assessed. Most tellingly, Odgers was able to show that in so-called bad streets, not only were there more cases of cholera in 1849 , but also a greater fatality rate from the disease. ${ }^{60}$

On 20 January Rawlinson went to inspect the slums of Plymouth for himself; what he found was apparently too grim to be reported in the press. He left Plymouth to prepare his controversial report, which he presented to the General Board of Health at the end of $1852 . .^{\circ 1}$ It amounted to an uncompromising and comprehensive indictment of the inefficiency and incompetence of both the Plymouth Town Council and the Plymouth Improvement Commissioners. The divided jurisdiction exercised by these two public bodies was identified as a principal obstacle to reform. Furthermore, Rawlinson alleged that Plymouth's public health problems were attributable, in part, to the "vicious constitution of the body of Commissioners". ${ }^{62}$ The challenge was clear, and neither local authority liked it. Their reaction was vehement and sustained.

\footnotetext{
57 R. Rawlinson, Report to the General Board of Health on the Borough of Birmingham, 1849, PRO, MH 13/27 Rawlinson's Report on street improvements in Bradford, 3 February 1851.

ss Plymouth and Devonport Weekly Journal, 15 January 1852, p. 8.

s9 Ibid.

60 Ibid., 22 January 1852, p. 2-3.

${ }^{61}$ Rawlinson, op. cit., note 3 above.

62 See also: PRO, MH 13/144 fo. 1189/53, Cookworthy to the GBH, 15 April 1853.
} 


\section{Local politics and public health in mid-nineteenth-century Plymouth}

By April 1853, the Improvement Commissioners had prepared their response to Rawlinson's report. A statement covering some eighteen pages was sent to the General Board of Health. They entirely refuted Rawlinson's findings. ${ }^{63}$ But they were prepared to acknowledge that their own powers had been too limited and they announced their intention of promoting a Plymouth Improvement Bill and a Plymouth Waterworks Bill as a remedy. Soon afterwards, the objections of the Town Council to Rawlinson's report were received in London. ${ }^{64}$ This time the emphasis was on the detailed figures and calculations contained in the report. Certainly the Council did seem to have uncovered some slight numerical discrepancies but the main thrust of the argument about Plymouth's woeful public health record remained unimpaired.

\section{THE ADOPTION OF THE PUBLIC HEALTH ACT}

Plymouth ratepayers had formed a committee by 1853 , and its new chairman, exTown Councillor Thomas Stevens, began to press the Board again in a fresh attempt to obtain local adoption of the terms of the 1848 Public Health Act. ${ }^{65}$ In March, a second petition was submitted, which indicated the scale of opposition to the two proposed local bills that had been designed to thwart those who wanted the Act applied. Some 5,400 townspeople recorded their opposition to the Waterworks Bill and the Improvement Bill, which were seen as window-dressing measures that would not mean any significant improvement in the sanitary condition of Plymouth. ${ }^{66} \mathrm{~A}$ month later, the Ratepayers' Committee began collecting information on the experience of other towns that had adopted the 1848 Act. Reaction in Exeter, Rugby, Tottenham, Launceston, Leamington, Wolverhampton, Derby, Southampton, Wigan, Gateshead, Salisbury, and York indicated that Chadwick's arrangements would cost only around $£ 100$ in legal expenses, while Plymouth's local bills were certain to cost $£ 3-£ 4,000$.67

By now, the General Board had accepted the evidence and was convinced that the Public Health Act of 1848 should be applied in Plymouth: "The Board are painfully aware of the defective sanitary condition of Plymouth and earnestly hope that the inhabitants may before long be enabled to apply the provisions of the Public Health Act to remedy the serious sanitary evils from which they are suffering." 68 But although a draft provisional order for the application of the Act to Plymouth had been prepared by September 1852, its progress was halted when there was a fresh outbreak of cholera in the town. The number of victims did not approach the scale of the 1849 epidemic, but there can be little doubt that the connexion between the incidence of the disease and bad conditions was clear again. Most of the cases this time were confined to the Irish quarter in St Andrew's sub-district, but they were sufficient to prompt the Commissioners to re-establish their temporary, independent local board of health, to appoint an "Inspector of Nuisances" (to clear away some of the filth), and to "take

\footnotetext{
${ }^{63}$ PRO, MH 13/144 fo. 1082/53, Commissioners to the GBH, 7 April 1853.

a PRO, MH 13/144 fo. 1170/53, Whiteford to the GBH, 14 April 1853.

os PRO, MH 13/144 fo. 960/53, Stevens to the GBH, 25 March 1853.

6 Ibid.

67 PRO, MH 13/144 fo. 962/53, Stevens to the GBH, 4 April 1853.

68 PRO, MH 13/144 fo. 1579/53, GBH to H. C. Martin, 27 May 1853.
} 


\section{Brayshay and V. F. T. Pointon}

active measures to counteract the progress of the disease". ${ }^{69}$ One Plymouth resident complained to Lord Palmerston about the town's cemeteries. As in 1849, graves were being re-used and the putrefying remains of earlier interments were being exposed when cholera victims were buried. Palmerston speedily referred the matter to both the General Board of Health and to the Plymouth Town Council. ${ }^{70}$ In a matter of days, the latter had responded with characteristically sharp words: "If Plymouth is in a deplorable sanitary condition let the General Board of Health answer for the results of its destructive interference with the efforts of the local authorities to effect improvement." "1

But Palmerston's intervention may well have been decisive. When a new provisional draft order for the application of the 1848 Act to Plymouth was issued in February 1854, the town council gave it their approval. Even the opposition of the Plymouth Improvement Commissioners was muted. They reiterated their earlier objection to the allegation that the two local authorities were in conflict, but they also realized that the battle was now lost. ${ }^{72}$ Parliament approved the incorporation of Plymouth under the terms of the Public Health Act in July 1854, and within weeks a permanent local board of health was being formed. ${ }^{73}$

\section{AFTERMATH: PLYMOUTH'S BOARD OF HEALTH}

The antagonisms provoked during the long, bitter campaign over the Public Health Act in Plymouth took years to heal. In the short term, this made the work of the new local board of health more difficult. Even so, the scale of their efforts is still impressive. ${ }^{74}$ Sewage disposal, paving streets with flagstones, and street-widening were amongst their early priorities. ${ }^{75}$ Work on an entirely new sewerage scheme was begun, which eventually received the approval of the General Board in August 1855. Costs were to be met by mortgaging the rates, and construction work began the following year. ${ }^{76}$ Under the terms of the Lands Clauses Consolidation Act of 1845, the Plymouth Board of Health framed a steady stream of provisional orders for the compulsory purchase of property to enable street improvements to be carried out. ${ }^{77}$ Hundreds of houses were demolished. It is ironic that initially this made overcrowding even worse, but the development of suburbs to the north and north-west of the town gradually eased the problem. ${ }^{78}$

By the end of the decade, the local board was administering public baths and washhouses recently purchased from the Ratepayers Committee and refurbished at a cost

\footnotetext{
69 PRO, MH 13/144 fo. 8/54, W. Pridham to GBH, 2 January 1854.

${ }^{70}$ PRO, MH 13/144 fo. 3923/53, T. J. Buswarva to Lord Palmerston; minuted by Palmerston and referred to the GBH.

"Ibid., Bampton to the GBH, 8 October 1853.

12 PRO, MH 13/144 fo. 1036/54, Eastlake to the GBH, 14 March 1854; also fo. 1061/54, 16 March 1854.

${ }_{73}$ PRO, MH 13/144 fo. 3327/54, Public Health Act Incorporation of Plymouth, 31 July 1854.

14 See, for example, PRO, MH 13/144 fos. 668/55, 719/55, 1890/55 and 3126/55.

75 PRO, MH 13/144 fo. 5031/54, Eastlake to the GBH, 5 October 1854; fo. 5283/54, Eastlake to the GBH 17 October 1854; fo. 107/55, Eastlake to the GBH 9 January 1855.

${ }^{76}$ PRO, MH 13/144 fo. 3287/55, GBH to Eastlake, 22 August 1855; and fo. 3339/55 Hodge to Eastlake, 25 August 1855.

" PRO, MH 13/145 fo. 1238/61; see also: Western Daily Mercury, 19 November 1864.

$n$ PRO, MH 13/145 fo. 1894/66, Plymouth Local Board of Health to the GBH; 30 June 1866.
} 
of over $£ 4,000.79$ Public parks were being cared for, including a new one formed on land once belonging to the Royal Ordnance on Plymouth Hoe. The wages of special Hoe policemen were included in the budget for the park. ${ }^{20}$ The location of slaughterhouses in the town was also under review, along with the siting of a number of other offensive trades." It had been recognized fairly quickly, however, that the powers of local boards were still somewhat limited - especially with regard to building standards. Plans for any new development had to be approved by the Board but, while it was possible to insist on changes in the position and size of drains, it was harder to force builders to alter proposed street alignments. ${ }^{82}$ As early as 1855 an attempt was made to regulate the heights of buildings in Plymouth. ${ }^{33}$ Several local developers objected, and the matter was referred to the General Board who ruled that, strictly speaking, the Act did not provide local boards with this particular power, although their reply suggests that Plymouth should at least make the attempt. ${ }^{24}$

Local documentation reveals the conscientious approach of the Plymouth Board of Health in such matters as nuisance removal (particularly the keeping of pigs in unsuitable premises) and street cleansing. ${ }^{85}$ Regulations on minimum street widths were established whereby no new streets could be less than thirty feet, and no back lane less than fourteen feet wide. 36 Many applications were rejected because they failed to comply with these rules. A house-to-house survey of water supply arrangements was begun, and eventually resulted in a vastly improved service. ${ }^{87}$ The board even undertook the complete rationalization of house numbering and street labelling in Plymouth.8s

Robert Rawlinson had declared in his report that Plymouth's "natural climate pronounced by physicians to be conducive to health - is by neglect allowed to become poisonous" ${ }^{89}$ After so long a period of neglect, it is no surprise to find that remedies were slow to take effect, but steady improvement began to occur in $1854 . .^{\circ}$

\section{CONCLUSION}

The accepted view of the 1848 Public Health Act is that it was more important for introducing the concept of public health in Britain rather than for any lasting practical effect. ${ }^{91}$ At national level this seems a fair assessment, but it tends to ignore the impact

\footnotetext{
${ }^{79}$ PRO, MH 13/144 fo. 3126/55, Eastlake to Sir Benjamin Hale, 4 August 1855.

${ }^{80}$ PRO, MH 13/144 fo. 541/55, GBH to Eastlake, 9 February 1855.

s1 PRO, MH 13/145 fo. 267/61, Rev. A. H. Greaves to Home Secretary, 14 February 1861.

${ }^{82}$ See, for example: DRO P4/A1 Plymouth Local Board of Health, Minutes of Proceedings, 9 March 1855; 4 June 1855; 2 August 1855.

${ }^{83}$ PRO, MH 13/144 fo. $719 / 55$, F. W. Pym to the GBH; fo. 720/55, GBH to Eastlake, 23 February 1855; fo. 805/55, Eastlake to the GBH, 27 February 1855.

4 Ibid., fo. 804/55, GBH to Eastlake, 28 February 1855.

ss DRO P4/A1, Plymouth Local Board of Health, Minutes of Proceedings: Inspector of Nuisances, 12 April 1855.

86 Ibid., 4 June 1855.

"7 Ibid., Sanitary Committee Proceedings, 31 January 1855.

Ibid., Special Committee on Street Numbering, Proceedings, 2 July 1856.

"Rawlinson, op. cit., note 3 above.

90 Certainly by the late 1870 s, Plymouth had achieved a lower mortality rate than many other cities of comparable size. At 14.6 per thousand it was appreciably lower than Manchester (21) or Newcastle (23).

${ }^{2}$ See F. B. Smith, The people's health, 1830-1910, London, Croom Helm, 1979, pp. 200-201.
} 
of the Act on local government in provincial towns. This study has shown how a local battle over the adoption of the 1848 Act in Plymouth led to fundamental changes in the management of urban affairs. ${ }^{92}$ The power of petitions and well-organized protest was tested on the public health issue and proved effective. But Plymouth was not unique; the same kind of dénouement has been observed elsewhere, though more studies will be needed before a full picture emerges. One clear conclusion to be drawn from this study is the key significance of public health in the political debate of midVictorian Plymouth.

\section{SUMMARY}

Mid-nineteenth century Plymouth was one of the country's most unhealthy towns. Cholera in 1832 and in 1849 was destructive, but the wastage of human life due to contaminated water supplies and bad housing was even more significant. Yet the local authorities opposed the application of the 1848 Public Health Act. They were afraid of losing political power in the borough, and waged a six-year campaign of resistance. But an outcry for the Act came from the ratepayers' association as well as private individuals. This detailed case study of Plymouth's quest to adopt the 1848 Act throws important light on the role of local politics in influencing public health in provincial towns in the middle of the last century.

\footnotetext{
92 By 1860 , a range of legislation that applied locally had been established by the Plymouth Local Board of Health on matters such as lodging-houses, slaughterhouses, open spaces, street widths, and access. Even so, Plymouth did not have a Medical Officer of Health until 1890 when Dr F. M. Williams was appointed to the post under the terms of the 1888 Local Government Act.
} 